MENTAL HOSPITALS, INSTITUTIONS, HOMES, ETC.

\title{
CHEADLE ROYAL
}

CHEADLE, CHESHIRE

A Registered Hospital for MENTAL DISEASES, and its Seaside Branch, GLAN-Y-DON, Colwyn Bay, N. Wales.

THE object of this Hospital is to provide the most efficient means for

1 the treatment and care of PATIENTS OF BOTH SEXES suffering from MENTAL and NERVOUS DISEASES. The

Hospital is governed by a Committee appointed by the Trustees of the Manchester Royal Infirmary.

VOLUNTARY, TEMPORARY and CERTIFIED PATIENTS RECEIVED.

For Terms and further information apply to the MEDICAL SUPERINTENDENT. Telephone: GATLEY 2231.

\section{CHISWICK HOUSE \\ A Private Hospital for the Treatment and Care of Mental and Nervous Illnesses in Both Sexes. \\ Phone: PINNER 234 \\ PINNER, MIDDLESEX}

A modern country house, 12 miles from Marble Arch, in attractive and secluded surroundings.

Fees from 10 guineas per week inclusive.

DOUGLAS MACAULAY, M.D., D.P.M.

\section{FEN S T A T T N}

(late Christchurch Road, S.W.2)

at HITCHAM PLACE, BURNHAM, Bucks.

A Private Home for the Care and Treatment of a limited number of Ladies with Mental and Nervous Disorders. Certified, Temporary and Voluntary Patients received. Large Country Mansion with twenty acres of grounds in Green Belt. Home-like surroundings. Apply : Dr. Madeline R. Lockwood, Resident Physician. Telephone: Burnham 624.

\section{HAYDOCK LODGE NEWTON-LE-WLLLWS, HAYDOCK LODGE, NDWN-LD- LANCASHIRE}

For the reception and treatment of PRIVATE PATIENTS of both sexes of the UPPER AND MIDDLE CLASSES suffering from Mental and Nervous Disorders, Alcoholism and Drug Addiction, either voluntary. temporary or under certificate. Patients are classified in separate buildings according to their mental condition.

Situated in park and grounds of 400 acres. Self-supported by its own farm and gardens in which patients are encouraged to occupy themselves. Every facility for indoor and outdoor recreation. For terms, prospectus. etc., apply MEDICAL SUPERINTENDENT.

Telegraphic Address : "Street." Ashton-in-Makerfield.

'Phone: 7311 Ashton-in-Makerfield. 
JOURNAL OF MENTAL SCIENCE CONTENTS FOR JULY, 1948

Original Articles-

PAGE

Post-hypoglycaemic Encephalopathy in Sakel's Insulin Treatment; by A. M. Spencer, M.B., B.Sc., D.P.M.

Posterior Cuts in Prefrontal Leucotomy: A Clinico-Pathological Study ; by Alfred Meyer, M.D., and Turner McLardy, M.B.E., B.Sc., M.B., Ch.B., D.P.M. .

A Psychiatric Review of Fifty Cases of Gunshot Wounds Self-inflicted; by $R$. F. Fidler, M.B., B.S., D.P.H.

The Results of Treatment of a Thousand Cases of Schizophrenia; by L. A. Finiefs, M.D.Paris, D.P.M.

Observations in Electrically-Produced Epileptic Convulsions. Part I: Tonic Neck and Labyrinthine Reflexes upon the Eyes; by $R$. Klein, M.D.Prague, and D. F. Early, L.R.C.P.ES.I., D.P.M. •

Periodic Catatonia; by J. S. Bonar Lindsay, M.B., Ch.B.(N.Z.) .

Misinterpretation of Mirror Image of Self in Presenile Cerebral Atrophy; by $R$. E. Hemphill, M.A., M.D., D.P.M. .

Contribution to the Dressing Disability as a Focal Sign and to the Imperception Phenomena; by $R$. E. Hemphill, M.D., and R. Klein, M.D.

The Community and the Aggressive Child; by $J . D . W$. Pearce, M.A., M.D., F.R.C.P.E., D.P.M.

The Ephedrine Treatment of Nocturnal Enuresis; by $G$. de $M$. Rudolf, M.R.C.P., D.P.M., D.P.H.

Further Aspects of Brief Retrograde Amnesia; by $\dot{G}_{\text {. }}$ de $M$. Rudolf, M.R.C.P., D.P.M., D.P.H.

Some Clinical Observations on the Psychodynamic Relationship between Depression and Obsessive-compulsive Symptoms; by E. Stengel, M.D.Vienna, L.R.C.P.Edin.

Lung Abscess following Electro-Convulsive Therapy: Description of a Case ; by Hugh Conway, B.Sc., M.B.Glasg., and Humphry Osmond, M.R.C.S., L.R.C.P.

Reviews

Chemistry of Muscular Contraction; by A. Szent-Gyorgyi.-Clinical Studies in Psychopathology; by Henry V. Dicks, M.D., F.R.C.P.Old Age: Its Compensations and Rewards; by A. L. Vischar, M.D.Foundations of Dreams Interpretation; by Samuel Lowy, M.D.Psychiatric Research ; Harvard University Press.-Current Therapies of Personality Disorders; by Bernard Glueck, M.D.-The Physical Background of Perception ; by E. D. Adrian, O.M., F.R.S.-Suicide and the Meaning of Life; by $M$. von Andico.-The Psychology of Behavior Disorders; by $N$. Cameron, M.D.-Practical Psychiatry and Mental Hygiene; by S. W. Hartwell, M.D.-A Text-book of Mental Deficiency (Amentia); by A.F. Tredgold, M.D., F.R.C.P.The Neocortex of Macaca Mulatta; by G. von Boñin and P. Bailey, -Diseases of the Nervous System; by W. Russell Brain.-Neurology; by Knud H. Krabbe, M.D.-Studies on the Morphogenesis of the Brain in Reptiles; by Knud H. Krabbe.-Studies on the Morphogenesis of the Brain in Lower Mammals; by Knud H. Krabbe.Studies on the Morphogenesis of the Brain in Hydracoidea, Ungulata, Carnivora and Pinnipedia; by Knud H. Krabbe.-The Practice of Mental Nursing; by May Houliston.

Bibliography and Epitome

I. Biochemistry. 